\title{
POST-HARVEST QUALITY OF OZONATED MACAUBA FRUITS FOR BIODIESEL PRODUCTION ${ }^{1}$
}

\author{
GUTIERRES NELSON SILVA ${ }^{2 *}$, JOSÉ ANTÔNIO SARAIVA GROSSI ${ }^{3}$, MARCELA SILVA CARVALHO $^{2}$, SAMUEL \\ DE MELO GOULART ${ }^{3}$, LÊDA RITA D'ANTONINO FARONI ${ }^{4}$
}

\begin{abstract}
The presence of microorganisms, especially during storage, can lead to the rapid deterioration of macauba fruits (Acrocomia aculeata) and reduce the quality of extracted oil for biodiesel production. An alternative to ensure the quality of the oil is the use of ozone gas, a oxidizing agent that has high antimicrobial and sanitizing power. The objective of this study was to evaluate the influence of high concentrations of ozone gas on macaúba fruit and its effect on the quality of the oil throughout storage for the production of biodiesel. Ozonation was performed 20 days after harvest using fruits with and without the epicarp. Ozone was applied at a concentration of $18.0 \mathrm{mg} \mathrm{L} \mathrm{m}^{-1}$ and a flow of $1.5 \mathrm{~L} \mathrm{~min}^{-1}$ for $10 \mathrm{~h}$. After ozonation, the fruits were stored for different periods, and the physical-chemical parameters of the oil were evaluated. The ozonation of fruits without the epicarp visually reduced microorganism attack. In general, the ozonation process of macauba fruits maintained the visual characteristics of the fruits and the physical-chemical characteristics of the oil for biodiesel production compared to untreated fruits. The average acidity values of the oil were lower in the treatments with the ozone gas. Removal of the epicarp tends to facilitate the ozonation process, potentially by improving gas penetration into the fruit.
\end{abstract}

Keywords: Acrocomia aculeate. Storage. Ozone gas. Oil.

\section{QUALIDADE PÓS-COLHEITA DE FRUTOS DE MACAÚBA OZONIZADOS PARA A PRODUÇÃO BIODIESEL}

\begin{abstract}
RESUMO - A presença de micro-organismo, especialmente durante o armazenamento, pode levar à deterioração rápida dos frutos de macaúba (Acrocomia aculeata) e reduzir a qualidade do óleo extraído para a produção de biodiesel. Uma alternativa para garantir a qualidade do óleo é o uso de gás ozônio, um poderoso agente oxidante que possui alto poder antimicrobiano e sanitizante. O objetivo deste estudo foi avaliar a influência do ozônio gasoso em alta concentração $\left(18,0 \mathrm{mg} \mathrm{L}^{-1}\right)$ em frutos de macaúba (com e sem epicarpo) e seu efeito sobre a qualidade do óleo durante todo o armazenamento para a produção de biodiesel. A ozonização foi realizada 20 dias após a colheita, utilizando frutas com e sem epicarpo. O ozônio foi aplicado na concentração de $18,0 \mathrm{mg} \mathrm{L}^{-1}$ e fluxo de $1,5 \mathrm{~L} \mathrm{~min}^{-1}$ durante $10 \mathrm{~h}$. Após a ozonização, os frutos foram armazenados por diferentes períodos e foram avaliados os parâmetros físico-químicos do óleo. A ozonização de frutos sem epicarpo reduziu visualmente o ataque de micro-organismos. Em geral, o processo de ozonização de frutos de macauba manteve as características visuais dos frutos e físico-químicas do óleo para produção de biodiesel em relação ao controle não tratado. Os valores médios de acidez do óleo foram menores nos tratamentos com o gás ozônio. A remoção do epicarpo tende a facilitar o processo de ozonização, já que a retirada pode facilitar a penetração do gás no fruto.
\end{abstract}

Palavras-chave: Acrocomia aculeate. Armazenamento. Gás ozônio. Óleo.

\footnotetext{
*Corresponding author

${ }^{1}$ Received for publication in $09 / 05 / 2017$; accepted in 08/08/2018

Paper extracted from the doctoral thesis of the first author.

${ }^{2}$ Instituto Federal de Educação, Ciência e Tecnologia do Maranhão, Codó, MA, Brazil; gutierres.silva@ifma.edu.br - ORCID: 0000-00024272-0634, marcela.carvalho@ifma.edu.br - ORCID: 0000-0002-8996-5743.

${ }^{3}$ Department of Plant Sciences, Universidade Federal de Viçosa, Viçosa, MG, Brazil; jgrossi@ufv.br - ORCID: 0000-0002-4671-5453, samucapitolio@yahoo.com.br-ORCID: 0000-0003-1307-2882.

${ }^{4}$ Department of agricultural engineering, Universidade Federal de Viçosa, Viçosa, MG, Brazil; 1faroni@gmail.com - ORCID: 0000-00018648-5034.
} 


\section{INTRODUCTION}

Macauba (Acrocomia aculeata) is a palm tree found in abundance in nature, mainly in tropical countries such as Brazil (SOUZA et al., 2016). The mesocarp of macauba fruit is an excellent source of vegetable oil for biodiesel production (AGUIEIRAS et al., 2014). According to Evaristo et al. (2016a), the production of oil in commercial plantations can reach $6.7 \mathrm{t} \mathrm{ha}^{-1}$ year $^{-1}$. This productivity is similar to that of the African palm (Elaeis guineensis), which is the agricultural crop with the highest yield of oil per hectare cultivated (CAVALCANTI-OLIVEIRA et al., 2015). However, the macauba crop is still in the transition phase from extractivism to rational cultivation, and several technologies need to be generated to sustain its commercial exploitation (PIMENTEL et al., 2015). One of the major bottlenecks in the agroindustrial chain is the storage of fruits so that industrial units can work year-round, since fruit production by this species is concentrated in the summer months. In addition, the macauba fruit has a rigid, semi-impermeable and cohesive husk (MONTOYA et al., 2016), which may hinder the use of post-harvest treatments

The post-harvest management of macauba fruits directly affects the quality of the extracted oil since growth and development of microorganisms can occur during fruit storage (EVARISTO et al., 2016b; CICONINI et al., 2013). The macauba presents a varied microbiota in the fruit mesocarp: $45.2 \%$ yeast, $32.6 \%$ bacteria and $22.2 \%$ fungi (EVARISTO et al., 2016b). According to Brazilian and European standards, biodiesel must have an acidity index $\leq 1.88 \%(0.5 \mathrm{mg} \mathrm{KOH} / \mathrm{g})$, oxidative stability $\geq 6 \mathrm{~h}$ and water content in oil $\leq 0.05 \%$ (CEN, 2003; ANP, 2008).

However, these characteristics are largely influenced by the raw material used (PINZI et al., 2009). Therefore, it is necessary to adopt fruit storage strategies to ensure the quality of oil for the production of biodiesel.

A modern alternative would be the use of ozone gas. Due to its oxidizing characteristics, ozone gas is effective against a broad spectrum of microorganisms (LAUREANO et al., 2016). Ozone acts on living organisms to promote damage to cell membranes or trigger cell death through oxidative stress (JOSHI et al., 2013).

The use of ozone in fruit post-harvesting has become attractive due to a number of advantages: it leaves no residue on the applied product and can be used in gaseous form or dissolved in water (JOSHI et al., 2013); its degradation product is oxygen (KARACA; VELIOGLU, 2007); and it can be generated locally, thus eliminating problems with storage and transportation (SOUSA et al., 2016).

The potential of ozone in controlling postharvest diseases in fruits is well-known; however, there is no information on the influence of ozone on the quality of macauba fruit during storage, as well as its effect on maintaining the quality of mesocarp oil. The aim of this work was to evaluate the influence of high-concentration ozone gas on macauba fruits and its effect on the quality of the oil throughout storage for the production of biodiesel.

\section{MATERIAL AND METHODS}

\section{Fruit harvest and place of study}

Macaúba fruits were obtained from plants growing in a natural population in the city of Acaiaca, MG, Brazil $\left(20^{\circ} 45^{\prime} 36^{\prime \prime} \mathrm{S} ; 4^{\circ} 15^{\prime} \mathrm{W}\right)$. The climate of the region, according to the classification of Köppen and Geiger (1928), is temperate humid with dry winters and hot summers (Cwa). These plants were identified, georeferenced and monitored. Bunches of physiologically mature fruits (start of mesocarp yellowing and natural abscission) were then detached from the mother plant.

The fruit ozonation process was conducted in the Department of Agricultural Engineering of the Federal University of Viçosa (UFV). Oil extraction and physical-chemical analyses of the oil were performed at the Post-Harvest Laboratory of Macauba, Department of Plant Science, UFV, both at the campus in Viçosa, MG, Brazil.

\section{Ozone gas generation and quantification}

Ozone gas was produced by an $\mathrm{O} \& \mathrm{~L}$ 10.0RM ozone generator (Ozone \& Life, São José dos Campos, SP, Brazil). In the gas generation process, moisture-free oxygen obtained by the concentrator of the generator was used as the input. The O\&LM ozone generator has two outputs: one through which the generated ozone is output and the other through which the atmospheric air obtained by an air compressor is coupled to the equipment. Ozone and atmospheric air (control) were distributed evenly to the cylindrical chambers in which the macaúba fruits were packed. The residual ozone was treated in a column containing KI solution. To quantify the ozone concentration, the iodometric method was used through indirect titration (APHA, 1981), as recommended by the International Ozone Association (IOA).

\section{Ozonation of fruits}

Freshly harvested (intact) macauba fruits were stored in the laboratory for 20 days (temperature $30 \pm 2{ }^{\circ} \mathrm{C}$ and relative humidity $70 \pm$ $5 \%$ ) (rest period). This storage was performed to allow oil accumulation in the mesocarp according to the results obtained by Goulart (2014). The analyses were performed 0 days post-harvest $\left(\mathrm{PH}_{0}\right)$ (initial characterization) and 20 days post-harvest $\left(\mathrm{PH}_{20}\right)$. 
Ozone was only applied to fruits on $\mathrm{PH}_{20}$. For the treatments with fruits originating from $\mathrm{PH}_{20}$, evaluations were performed on husked (HU) and dehusked fruits (DH). The removal of the epicarp was performed manually prior to ozonization. After this procedure, $\mathrm{HU}$ and $\mathrm{DH}$ fruits were submitted to ozone treatment. Four treatments were applied: ozonization with epicarp (O-HU), ozonation without epicarp (O-DH), control with epicarp (C-HU) and control without epicarp (C-DH). Then, the fruits of all treatments were stored for $0,10,20,30$ and 40 days $(\mathrm{SP}=$ storage period) in plastic boxes (temperature $30 \pm 2{ }^{\circ} \mathrm{C}$ and relative humidity $70 \pm$ $5 \%$ ). Each sample unit consisted of 15 fruits packed in plastic nets. Four replicates were used for each treatment.
The ozonation process was performed in cylindrical PVC chambers $(20 \mathrm{~cm}$ diameter x $100 \mathrm{~cm}$ height) with lower and upper connections for the inlet and outlet of ozone and atmospheric air, respectively (Figure 1). In each chamber, a metal screen was installed, $10 \mathrm{~cm}$ from the bottom, to support the fruits and form a plenum to improve the gas distribution. Ozone was applied at a concentration of $18 \mathrm{mg} \mathrm{L}^{-1}$ and a continuous flow of $1.5 \mathrm{~L} \mathrm{~min}^{-1}$ for $10 \mathrm{~h}$. The high concentration and exposure period were selected based on preliminary experiments and work by Alencar et al. (2011). The same system was used to provide only atmospheric air (control treatment). All assays were conducted under constant temperature $\left(27 \pm 2{ }^{\circ} \mathrm{C}\right)$ and relative humidity $(70 \pm 5 \%)$.

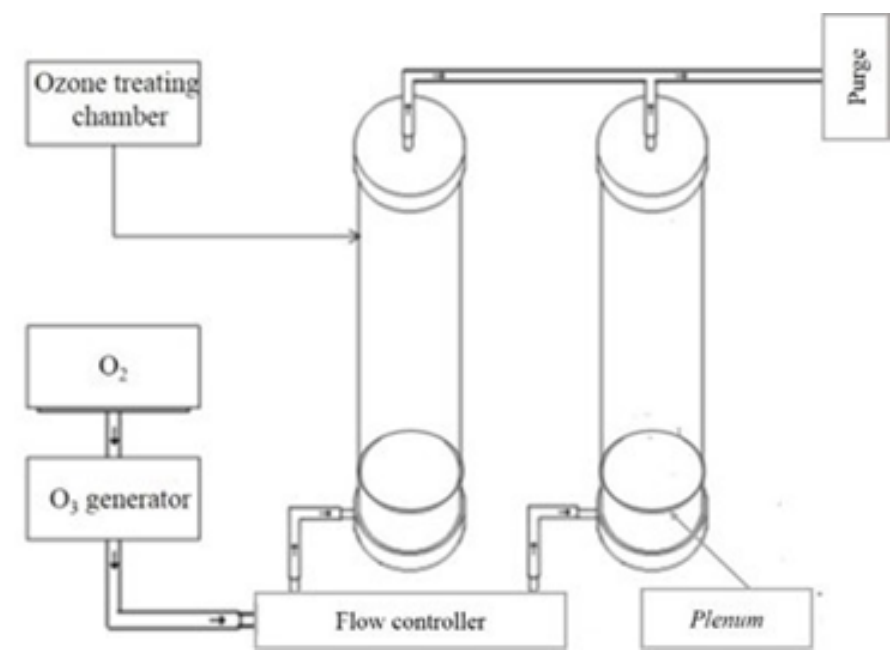

Figure 1. Schematic diagram of the experimental setup (Adapted from Rozado, 2005).

\section{Mesocarp oil content, extraction and physical- chemical analysis}

For the oil extraction, minced mesocarp was dried at $60^{\circ} \mathrm{C}$ for $15 \mathrm{~h}$ and then pressed by a stainless steel hydraulic press. The obtained oil was stored in amber bottles, which were wrapped in aluminum foil and stored at $-20^{\circ} \mathrm{C}$ until further analyses.

Fruit samples were collected for analysis of oil content of the mesocarp and oil properties at two time points: i) 0 days post-harvest $\left(\mathrm{PH}_{0}\right)$ and ii) after 20 days of storage $\left(\mathrm{PH}_{20}\right)$ for treatments $(\mathrm{O}-\mathrm{HU}, \mathrm{O}-$ $\mathrm{DH}, \mathrm{C}-\mathrm{HU}$ and $\mathrm{C}-\mathrm{DH})$ for each storage period established $(0,10,20,30$ and 40 days). On the first occasion $\left(\mathrm{PH}_{0}\right)$, only $\mathrm{HU}$ fruits were sampled. This sampling was performed to characterize the material before treatment.

The oil content of the mesocarp was determined by nuclear magnetic resonance (NMR). An MQC NMR Analyzer (Oxford Instruments, Abingdon, UK) was used, and the oil content was expressed as the percentage on dry basis (d.b.) according to ISO method 10565 (ISO, 1999). This method was chosen after determining its precision compared to OC results obtained using an oil extractor (AOAC INTERNATIONAL, 1992).

Oxidative stability was evaluated according to the $\mathrm{CD}$ 12b-92 method (AOAC INTERNATIONAL, 2005) using Rancimat $\AA$ equipment (model 873 Biodiesel Rancimat, USA). The results were expressed in hours, where the induction period indicates the oxidative stability of the oil.

The free fatty acid content was determined according to the $\mathrm{Ca} 5 \mathrm{a}-40$ method (AOAC INTERNATIONAL, 2005) and converted to the acidity percentage in oleic acid.

The water content in the oil was measured based on ASTM D 6304 by an automatic titrator model 870 KF Titrino Plus (Metrhom, Switzerland). Karl Fischer solution was used as the titrant solution, and to solubilize the samples, a mixture containing 1: 1 methanol and chloroform was used.

\section{Experimental design and statistical analysis}

The experiment was installed in a subdivided plot scheme in a $2 \times 2$ factorial scheme: exposure 
types (ozone and atmospheric air) and fruit types (with and without epicarp). In the subplots, the storage periods $(0,10,20,30$ and 40 days) were arranged in a completely randomized design (DIC). Each sample unit contained 15 fruits. For each treatment, four replicates were used, totaling 1200 fruits. Data were submitted to analysis of variance (5\% of significance). For the qualitative factor, means were compared using the Tukey test at $5 \%$ probability. For the quantitative factor, data were submitted to analysis of regression. The models were chosen based on the significance of the regression coefficients using the " $t$ " test, the coefficient of determination $\left(\mathrm{R}^{2}\right)$ and the biological phenomenon. Regardless of whether the higher-degree interaction was significant or not, it was unfolded due to the interest of the study.

\section{RESULTS AND DISCUSSION}

\section{Visual changes in fruits after the treatments and storage periods}

The visual changes in the fruit mesocarp after the ozonation and control treatments $(\mathrm{O}-\mathrm{HU}, \mathrm{O}-\mathrm{DH}$, $\mathrm{C}-\mathrm{HU}$ and $\mathrm{C}-\mathrm{DH}$ ) during different storage periods are presented in Figure 2. In the $\mathrm{C}-\mathrm{HU}$ and $\mathrm{O}-\mathrm{HU}$ fruits, deterioration due to microorganisms was similar throughout storage. These results demonstrate that the ozonation process $\left(18 \mathrm{mg} \mathrm{L}^{-1}\right.$ for $10 \mathrm{~h}$ ) of macauba fruits with the epicarp was not effective in controlling post-harvest diseases. The epicarp is a natural barrier to water loss. (BENNAMOUN; KHAMA; LÉONARD, 2015). This barrier possibly prevented the entry of the ozone gas. Other factors may also affect ozone toxicity, such as ozone gas concentration, exposure time, fruit morphological characteristics, and location of microorganism occurrence, among others. In both treatments (C-HU and O-HU), signs of deterioration by microorganisms were observed after 10 days of storage.

By contrast, treatment of fruits without the epicarp with ozone (O-DH) gas resulted in a visual reduction of microorganisms at up to 20 days of storage. The ozone gas may have acted as an inhibitor of the growth and development of the microorganisms presents in these fruits. A variable microbiota emerges during the storage of macaúba fruits (EVARISTO et al., 2016b). According to Evaristo et al. (2016b) during the storage of macaúba fruits under environmental conditions, microorganisms appeared in the following proportion: $45.2 \%$ yeast, $32.6 \%$ bacteria and $22.2 \%$ fungi. Our results suggest that epicarp removal prior to the ozonation process may represent a macauba fruit storage technique. Several studies have reported toxic effects of ozone on microorganisms present in fruits. Gabler et al. (2010) also observed a reduction of microorganisms in fruits of grapes after ozonation with high gas concentrations $(2500,5000$ and 10000 $\left.\mu \mathrm{L} \mathrm{L}^{-1}\right)$. Alencar et al. (2014) studied the effect of ozone on the post-harvest conservation of pear fruits and also verified preservation of the visual quality of the fruits after treatment with $100 \mu \mathrm{L} \mathrm{L}^{-1}$ ozone for $60 \mathrm{~min}$ and storage for 13 days. During the ozonation process, microorganisms are inactivated by molecular ozone or free radicals. This inactivation occurs due to the lysis of the cellular envelope and release of the cytoplasmic content (CULLEN et al., 2010). In addition, anomalies were observed on the mesocarp of the macauba fruits in the O-DH treatment, which were characterized by orange coloration. These anomalies began to be observed 10 days after ozone application. Similarly, Ong et al. (2014), when ozonating papaya fruits at different concentrations $\left(3.5\right.$ and $\left.5 \mu \mathrm{L} \mathrm{L}^{-1}\right)$ for $96 \mathrm{~h}$, observed brown spots on the fruit surface. According to Ong et al. (2014) high concentrations of ozone can cause damage to the fruit tissue. Because it is a powerful oxidizing agent, ozone gas can cause some anomalies (ALI; ONG; FORNEY, 2014).

Due to the toxic potential of ozone gas, this technology represents a potential alternative for the conservation of macauba fruits during storage.

\section{Physical-chemical characteristics of mesocarp oil}

After harvest, the oil content (OC), on average, was $47.65 \%$ dry basis (d.b.) (Table 1). After the storage period for natural accumulation of oil in the mesocarp (20 days), there was an increase in OC of $11.7 \%$ (d.b.). The OC after 20 days was superior to the value of $52 \%$ (d.b.) reported by Evaristo et al. (2016b). According to Evaristo et al. (2016b) this variation is due to the different biomes at the sites where the fruits were collected. The increase in OC after harvest is due to the possible climacteric respiration pattern of the fruits, which results in postharvest fruit ripening (EVARISTO et al., 2016b).

The mean values of OC were not affected $(P$ $>0.05)$ by the treatments with ozone or atmospheric air (control) or fruit type (HU and $\mathrm{DH}$ ) for all storage periods (SPs). The mean OC values of the macauba fruits ranged from 58.03 to $62.56 \%$ (d.b.) for all treatments in the different SPs (Figure $3 \mathrm{~A}$ and Figure 4A). This behavior implies that the ozone gas $\left(18 \mathrm{mg} \mathrm{L}^{-1}, 10 \mathrm{~h}\right)$ does not affect the OC of the macauba fruits, regardless of the presence or absence of the epicarp, throughout the storage period. 


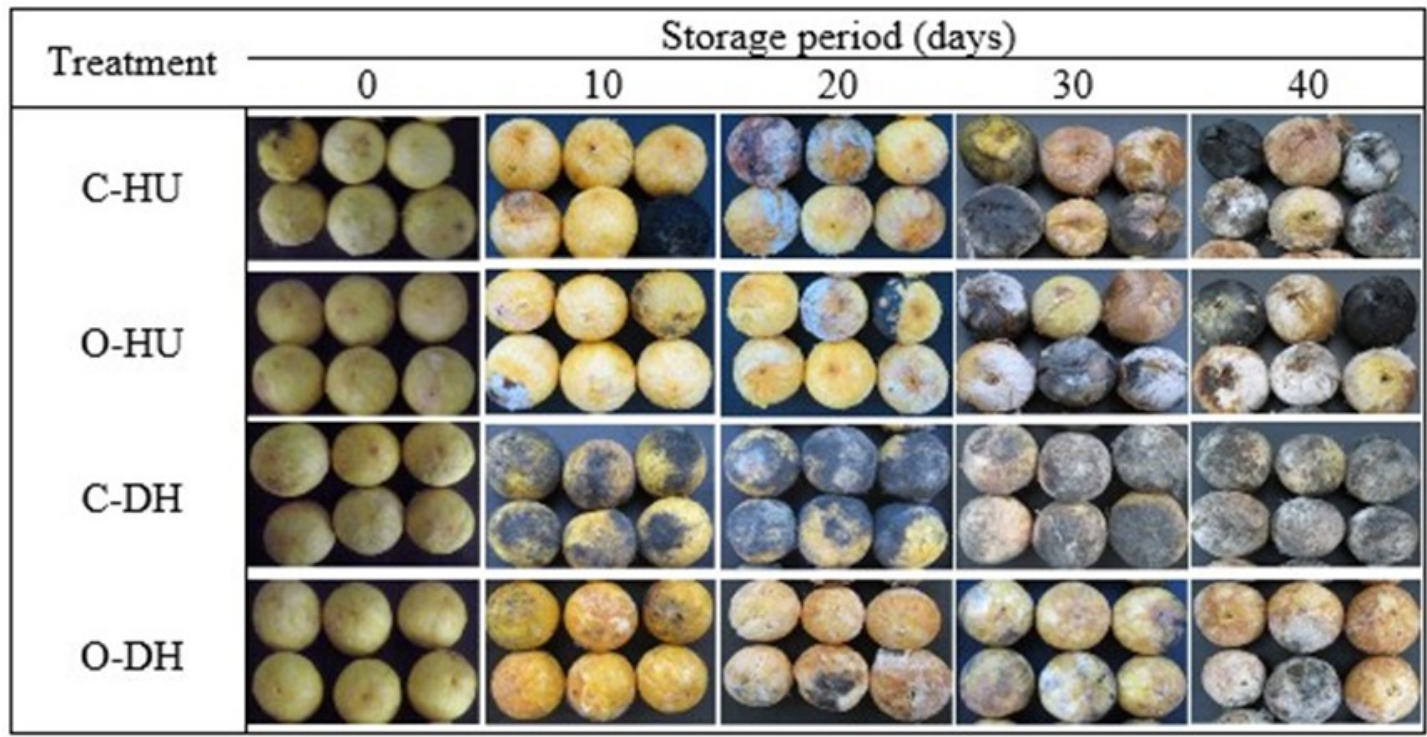

Figure 2. Visual analysis of the mesocarp of macaúba fruits submitted to ozonation with epicarp (O-HU), ozonation without epicarp (O-DH), control with epicarp (C-HU) and control without epicarp (C-DH) throughout storage (0, 10, 20, 30 and 40 days).

The results of the present study corroborate the results of Alencar et al. (2011), who studied the effect of ozone at high concentrations $(13$ and $21 \mathrm{mg}$ $\left.\mathrm{L}^{-1}\right)$ and different exposure periods $(0,24,48,72$ and $96 \mathrm{~h}$ ) on crude peanut oil quality. Alencar et al. also verified that ozone exposure did not affect the oil content of the grains compared to the control. The results of this study demonstrate the high yield of macauba oil, thus confirming the suitability of the species as a raw material for the production of biodiesel. In addition, this study demonstrates that post-harvest technology including ozone gas does not affect OC, regardless of the presence or absence of the epicarp during storage.

Table 1. Results of the analyses of the mesocarp oil of macaúba fruits after harvest $\left(\mathrm{PH}_{0}\right)$ and 20 days after harvest $\left(\mathrm{PH}_{20}\right)$. The following analyses were performed: oil content (OC), acidity index (FFA), oxidative stability (OS) and water content in oil (WC).

\begin{tabular}{lcc}
\hline \multirow{2}{*}{ Analyses } & \multicolumn{2}{c}{ Sampling period } \\
\hline Oil content (\% d.b.)* & $\mathrm{PH}_{0}$ & $\mathrm{PH}_{20}$ \\
Acidity index (\% oleic acid) & $47.65 \pm 0.54^{* *}$ & $59.35 \pm 0.70$ \\
Oxidative stability (h) & $0.63 \pm 0.06$ & $2.18 \pm 0.67$ \\
Water content in oil (\%) & $16.91 \pm 1.21$ & $12.60 \pm 2.27$ \\
& $0.16 \pm 0.01$ & $0.06 \pm 0.01$ \\
\hline
\end{tabular}

*d.b. - dry basis. $* *$ mean \pm standard error of the mean.

The oxidative stability (OS) of the mesocarp oil was, on average, $16.95 \mathrm{~h}$ after harvest and 12.60 $\mathrm{h}$ after 20 days of storage $\left(\mathrm{PH}_{20}\right)$ (Table 1). The OS was not influenced $(\mathrm{P}>0.05)$ by the treatments with or without (control) ozone application, except at
$\mathrm{SP}=0$ (Figure 3B). With respect to the ozonation process, the OS of the mesocarp oil from fruits in the $\mathrm{O}-\mathrm{HU}$ treatment was significantly higher $(P<0.05)$ than that of mesocarp oil from fruits in the O-DH treatment in the different SPs. 


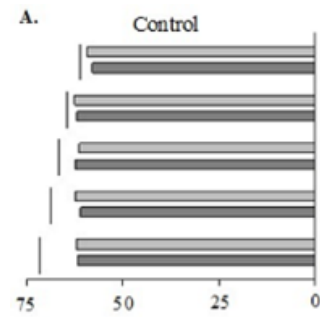

Pulp oil content $(\% \mathrm{db})$

c.
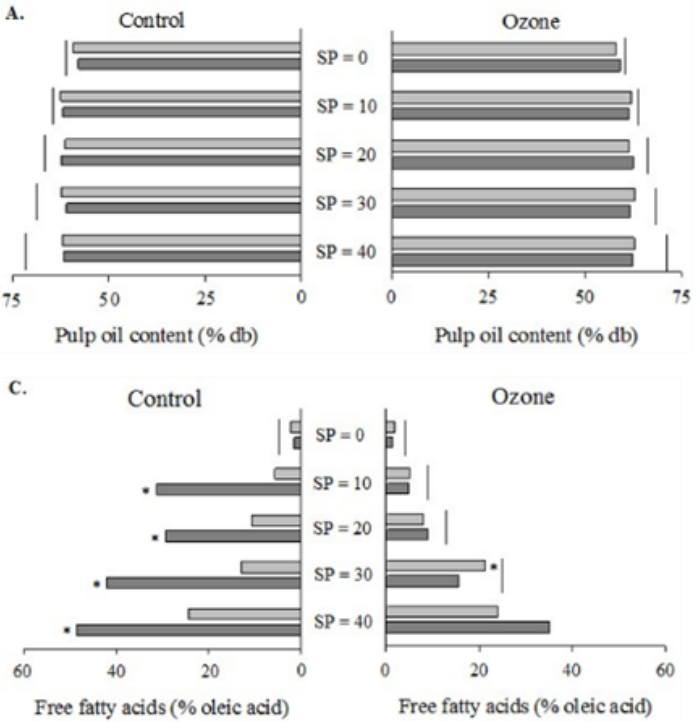

B.

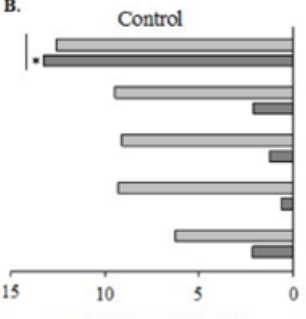

Oxidative stability (h)

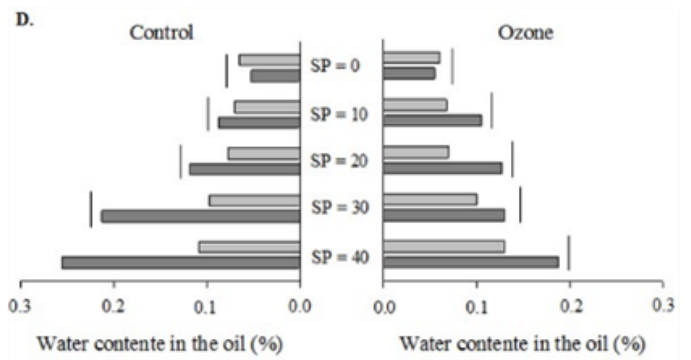

Figure 3. Mean values of pulp oil content (A), oxidative stability (B), free fatty acids (c) and water content in oil (D) for the oil of macauba fruits exposed to ozone and atmospheric air (control) with epicarp (HU) and without epicarp (DH) for different periods of storage (SP). Means grouped with bars at the same height do not differ between fruit types (HU and $\mathrm{DH})$ by Tukey's test $(P>0.05)$. The asterisks indicate significant differences between treatments (ozone and control) for each type of fruit (HU and DH) in each SP by Tukey's test $(P<0.05)$.
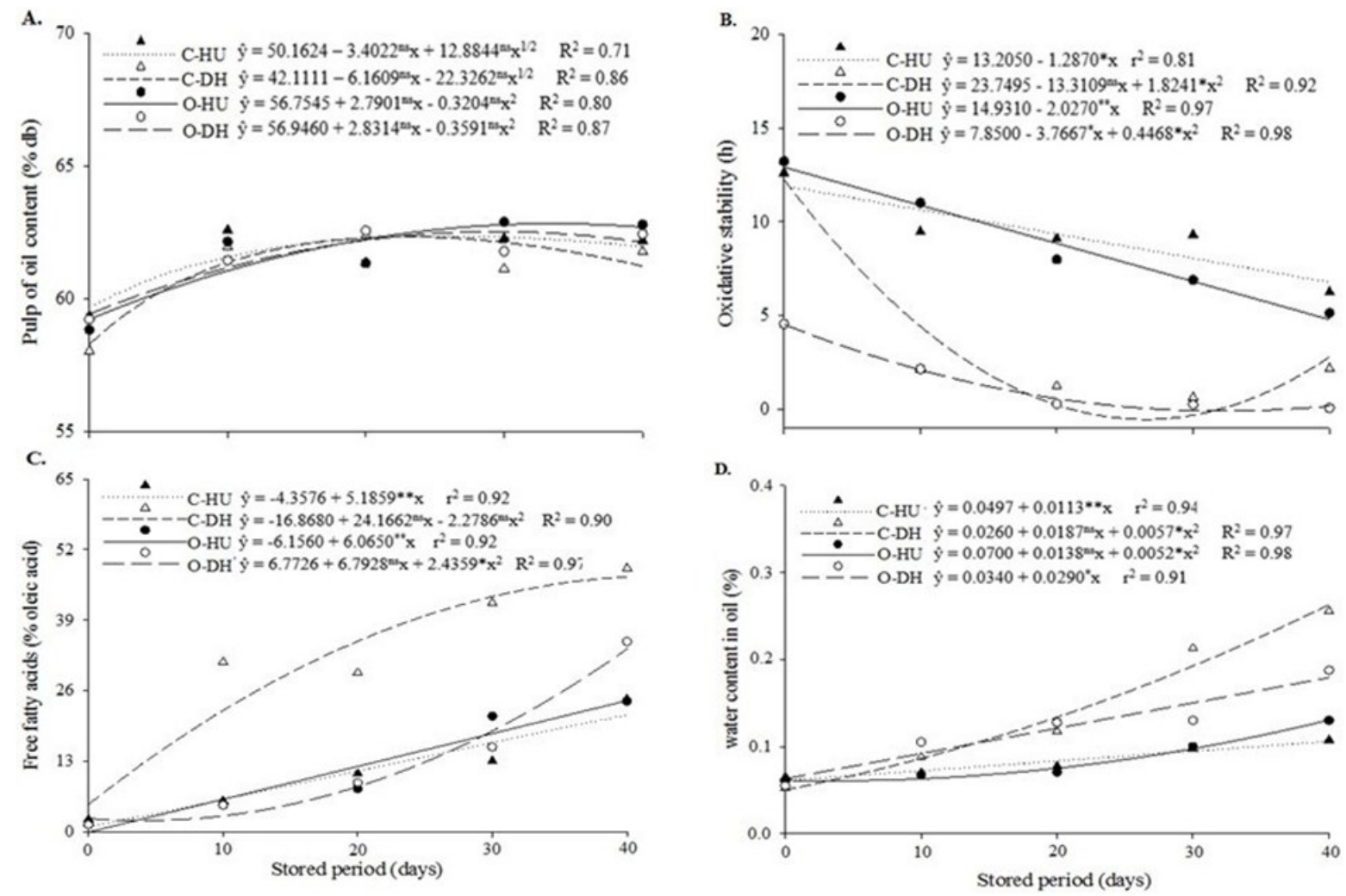

Figure 4. Oil content (A), oxidative stability (B), acidity index (C) and water content in oil (D) for the oil of macauba fruits exposed to O-HU and O-DH at a concentration of $18 \mathrm{mg} \mathrm{L}^{-1}$ and exposure period of $10 \mathrm{~h}$ or atmospheric air (C-HU and CDH) throughout storage $(0,10,20,30$ and 40 days $) . *$ Significant at $5 \%, * *$ significant at $1 \%$ and 'ns' not significant by ttest. 
Because ozone is a powerful oxidizing agent, when it came into direct contact with the mesocarp of the fruits without epicarp (protection), it may have accelerated the oxidation process of the oil and, consequently, reduced the OS. In addition, it is important to note that the oxidation rate of the oil is affected by the fatty acid composition, the degree of unsaturation of alkyl esters and the position of the double bonds in the carbon chains (BOUAID; MARTINEZ; ARACIL, 2007; EVARISTO et al., $2016 \mathrm{~b})$. The mesocarp oil of macaúba contains approximately $78 \%$ unsaturated fatty acids, particularly oleic acid. This fatty acid profile, which is composed mainly of unsaturated fatty acids, favors oxidation of the macauba mesocarp oil (GOULART, 2014).

There was a reduction of OS with increasing SP in all treatments, and after 20 days of storage after the O-DH treatment, the mean OS values were close to zero (Figure 3B). The Brazilian and European standards for oil oxidative stability (CEN, 2003; ANP, 2008) establish an induction period of at least $6 \mathrm{~h}$ for biodiesel. Our results indicate that it is possible to maintain the oil quality of macauba mesocarp at acceptable OS levels up to 50 days (20 days rest at $25^{\circ} \mathrm{C}+30$ days after $\mathrm{O}-\mathrm{DH}$ treatment).

The acidity of the oil is one of the most important parameters for biodiesel production (TAN et al., 2009). The free fatty acids (FFA) in the mesocarp oil after harvest was, on average, $0.63 \%$ (Table 1). Results with low mean FFA values of $1.1 \%$ were reported by Nunes et al. (2015).

In general, FFA varied $(P<0.05)$ between treatments (ozone and atmospheric air) and fruit type (HU and DH) (Figure 3C). With respect to the ozonation process, no significant difference $(P>$ 0.05 ) was observed between fruits $\mathrm{HU}$ and $\mathrm{DH}$, except at $\mathrm{SP}=30$. Notably, at $\mathrm{SP}=0$, average values of FFA of less than $1.88 \%$ were observed in the treatments with the ozone gas. In Brazil, according to the National Petroleum Agency (ANP) standard, the acid limit for biodiesel is $0.5 \mathrm{mg} \mathrm{KOH} . \mathrm{g}^{-1}(1.88 \%)$ (ANP, 2008).

The fruits from the O-DH treatment had lower mean FFA values $(P<0.05)$ compared to the fruits of the C-DH treatment for the different SPs, except $\mathrm{SP}=0$. Similar results were obtained by Alencar et al. (2011), which did not find significant differences in the FFA of oil from peanut grains immediately after ozone application $(\mathrm{SP}=0)$ compared to the control treatment. Akbas and Ozdemir (2006), in a study of the effect of different treatments with ozone (concentrations: 0.0, 5.0, 7.0 and $9.0 \mathrm{mg} \mathrm{L}^{-1}$; exposure periods: 140 and $420 \mathrm{~min}$ ) on the degradation of aflatoxins and the physicalchemical properties of Pistacia vera, also did not observe differences in the FFA of the oil immediately after ozonization.

An increase in FFA was observed with increasing SP for all treatments (Figure 3C).
However, these increases were more pronounced in fruits without the epicarp. In addition, throughout storage, fruits from the $\mathrm{C}-\mathrm{DH}$ treatment presented higher FFA values. The considerable increase in acidity during the storage period is associated with the presence of microorganisms in all treatments. Tagoe, Dickinson and Apetorgbor (2012) also observed an increase in FFA in palm fruits throughout storage. According to Ali, Shamsudin and Yunus (2014), microbial attack favors the hydrolysis of oil and, consequently, an increase in FFA. According to Evaristo et al. (2016b), the rapid increase in FFA is probably due to the joint action of the lipase enzymes from fruits and microorganisms.

The water content in oil (WC) after harvest was, on average, $0.16 \%$ (Table 1 ). In general, there were no significant differences $(P>0.05)$ in WC among any of the treatments studied (Figure 3D). As the storage period of the macauba fruits increased, WC increased for all treatments, with the highest average values observed in the treatments from the control (Figure 4D). Brazilian and European standards (CEN, 2003; ANP, 2008) establish a maximum of $0.05 \%$ water content in biodiesel. With respect to the application of ozone, the O-DH treatment at $\mathrm{SP}=0$ days presented an average $\mathrm{WC}$ of $\leq 0.05 \%$. Thus, these results are within the acceptable range for biodiesel production, suggesting that the removal of the epicarp prior to the ozonation process is a viable technique for maintaining $\mathrm{WC}$ in macauba fruits postharvest.

\section{CONCLUSIONS}

In general, the ozonation process of macauba fruits maintained the visual characteristics of the fruits and the physical-chemical characteristics of the oil for biodiesel production compared to the untreated fruits. The average acidity values of the oil were lower in the treatments with ozone gas. Removal of the epicarp tended to facilitate the ozonation process, potentially by facilitating gas penetration into the fruit.

\section{ACKNOWLEDGMENTS}

This work was supported by the Brazilian agencies National Council for Scientific and Technological Development (CNPq) and Coordination for the Improvement of Higher Education Personnel (CAPES) and by the Plant Science Department of the Federal University of Viçosa (UFV). 


\section{REFERENCES}

AGUIEIRAS, E. C. G. et al. Biodiesel production from Acrocomia aculeata acid oil by (enzyme/ enzyme) hydroesterification process: use of vegetable lipase and fermented solid as low-cost biocatalysts. Fuel, v. 135, n. 1, p. 315-321, 2014.

AKBAS, M. Y; OZDEMIR, M. Effect of different ozone treatments on aflatoxin degradation and physicochemical properties of pistachios. Journal of the Science of Food and Agriculture, v. 8, n. 13, p. 2090-2104, 2006.

ALENCAR, E. R. et al. effectiveness of ozone on postharvest conservation of pear (Pyrus communis L.). Food Processing \& Technology, v. 5, n. 4, p. 15,2014

ALENCAR, E. R. et al. Effect of the ozonization process on the quality of peanuts and crude oil. Revista Brasileira de Engenharia Agrícola e Ambiental, v. 15, n. 2, p. 154-160, 2011.

ALI, A.; ONG, M. K.; FORNEY, C. F. Effect of ozone pre-conditioning on quality and antioxidant capacity of papaya fruit during ambient storage. Food Chemistry, v. 142, n. 1, p. 19-26, 2014.

ALI, F. S.; SHAMSUDIN, R.; YUNUS, R. The effect of storage time of chopped oil palm fruit bunches on the palm oil quality. Agriculture and Agricultural Science Procedia, v. 21, n. 1, p. 65172, 2014.

AGÊNCIA NACIONAL DO PETRÓLEO, GÁS NATURAL E BIOCOMBUSTÍVEIS - ANP. Number 7 biodiesel standard. In: National Agency of Petroleum. Natural Gas and Biofuels, Brazil, 2008.

ASSOCIATION OF OFFICIAL AGRICULTURAL CHEMISTS - AOAC INTERNATIONAL. Official methods of analysis of the Association of Official. In: Analytical Chemists. Association of Official Analytical Chemists, Washington, 1992.

ASSOCIATION OF OFFICIAL AGRICULTURAL CHEMISTS - AOAC INTERNATIONAL. Official Methods of Analysis of the Association of Official Analytical Chemists. Association of Official Analytical Chemists, Gaithersburg, 2005.

AMERICAN PUBLIC HEALTH ASSOCIATION APHA. Standard methods for the examination of water and wastewater. 15 ed. APHA American Public Health Association, 1981. 1134 p.

BENNAMOUN, L.; KHAMA, R.; LÉONARD, A. Convective drying of a single cherry tomato:
Modeling and experimental study. Food and Bioproducts Processing, v. 94, n. 1, p. 114-123, 2015.

BOUAID, A.; MARTINEZ, M.; ARACIL, J. Long storage stability of biodiesel from vegetable and used frying oils. Fuel, v. 86, n. 16, p. 2596-2602, 2007.

CAVALCANTI-OLIVEIRA, E. D. et al. Methods to prevent acidification of Macaúba (Acrocomia aculeata) fruit pulp oil: A promising oil for producing biodiesel. Industrial Crops and Products, v. 77, n. 1, p. 703-707, 2015.

CICONINI, G. et al. Biometry and oil contents of Acrocomia aculeata fruits from the Cerrados and Pantanal biomes in Mato Grosso do Sul, Brazil. Industrial Crops and Products, v. 45, n. 1, p. 208214, 2013.

$\begin{array}{lcc}\text { EUROPEAN COMMITTEE } & \text { FOR } \\ \text { STANDARDIZATION } & - \text { CEN. EN } & \text { 14214- } \\ \text { Biodiesel Standard. } & \text { European } & \text { Standard } \\ \text { Organization, Brussels, 2003. } & \end{array}$

CULLEN, P. J. et al. Ozone processing for food preservation: an overview on fruit juice treatments. Ozone: Science \& Engineering, v. 32, n. 3, p. 166$179,2010$.

EVARISTO, A. B. et al. Actual and putative potentials of macauba palm as feedstock for solid biofuel production from residues. Biomass Bioenerg, v. 85, n. 1, p. 18-24, $2016 \mathrm{a}$.

EVARISTO, A. B. et al. Harvest and post-harvest conditions influencing macauba (Acrocomia aculeata) oil quality atributes. Industrial Crops and Products, v. 85, n. 1, p. 63-73, 2016 b.

GABLER, F. M. et al. Influence of fumigation with high concentrations of ozone gas on postharvest gray mold and fungicide residues on table grapes. Postharvest Biology and Technology, v. 55, n. 2, p. 85-90, 2010.

GOULART, S. M. Amadurecimento pós-colheita de frutos de macaúba e qualidade do óleo para a produção de biodiesel. 2014. 66f. Dissertação (Mestrado em Fitotecnia: Área de Concentração em Produção vegetal) - Universidade Federal de Viçosa, Viçosa, 2014

ISO $10565 . \quad$ Oilseeds-Simultaneous Determination of Oil and Moisture ContentsMethod Using Pulsed Nuclear Magnetic Resonance Spectrometery. International Organization for Standardization, Geneva, Switzerland, 1999. 
JOSHI, K. et al. Novel disinfectants for fresh produce. Trends in Food Science \& Technology, v. 34, n. 1, p. 54-61, 2013.

KARACA, H.; VELIOGLU, Y. S. Ozone applications in fruit and vegetable processing. Food Reviews International, v. 23, n. 1, p. 91-106, 2007.

KÖPPEN, W.; GEIGER, R. Klimate der Erde. Gotha: Verlag Justus Perthes. Wall-map $150 \mathrm{~cm} \times 200 \mathrm{~cm}, 1928$.

LAUREANO, J. et al. Effects of continuous exposure to ozone gas and electrolyzed water on the skin hardness of table and wine grape varieties. Journal of Texture Studies, v. 47, n. 1, p. 40-48, 2016.

MONTOYA, S. G. et al. Fruit development, growth, and stored reserves in macauba palm (Acrocomia aculeata), an alternative bioenergy crop. Planta, v. 244, n. 4, p. 927-938, 2016

NUNES, A. A. et al. Good practices of harvest and processing provide high quality Macauba pulp oil. European Journal of Lipid Science and Technology, v. 117, n. 12, p. 2036-2043, 2015.

ONG, M. K. et al. Effect of different concentrations of ozone on physiological changes associated to gas exchange, fruit ripening, fruit surface quality and defence-related enzymes levels in papaya fruit during ambient storage. Scientia Horticulturae, v. 179, n. 1, p. 163-169, 2014

PIMENTEL, L. D. et al. effect of nitrogen and potassium rates on early development of macaw palm. Revista Brasileira de Ciência do Solo, v. 39, n. 6, p. 1671-1680, 2015.

PINZI, S. et al. The ideal vegetable oil-based biodiesel composition: a review of social: economical and technical implications. Energy Fuels, v. 23, n. 5, p. 2325-2341, 2009.

ROZADO, A. F. Ozônio como fumigante na proteção de milho armazenado. 2005 46p. Dissertação (Mestrado em Engenharia Agrícola:Área da Concentração em Armazenamento e Processamento de Produtos Agrícolas) Universidade Federal de Viçosa, Viçosa, 2005.

SOUSA, A. H. et al. Ozone toxicity to Sitophilus zeamais (Coleoptera: Curculionidae) populations under selection pressure from ozone. Journal of Stored Products Research, v. 65, n. 1, p. 1-5, 2016. crude macauba oil (Acrocomia aculeata) for biodiesel production. Fuel, v. 165, n. 1, p. 360-366, 2016.

TAGOE, S. M. A.; DICKINSON, M. J.; APETORGBOR, M. M. Factors influencing quality of palm oil produced at the cottage industry level in Ghana. International Food Research Journal, v. 19, n. 1, p. 271-278, 2012.

TAN, C. H. et al. Extraction and physicochemical properties of low free fatty acid crude palm oil. Food Chemistry, v. 113, n. 2, p. 645-650, 2009.

SOUZA, G. K. et al. Synthesis of ethyl esters from 